\title{
Human Papillomavirus and Potentially Relevant Biomarkers in Tonsillar and Base of Tongue Squamous Cell Carcinoma
}

\author{
ANDERS NÄSMAN ${ }^{1}$, CINZIA BERSANI $^{1}$, DAVID LINDQUIST $^{2}$, JUAN DU $^{3}$, \\ TORBJÖRN RAMQVIST ${ }^{1}$ and TINA DALIANIS ${ }^{1}$ \\ ${ }^{1}$ Department of Oncology-Pathology, Karolinska Institutet, Stockholm, Sweden, \\ ${ }^{2}$ Department of Radiation Sciences, Umeå University, Umeå, Sweden; \\ ${ }^{3}$ Department of Microbiology, Tumor Biology and Cell Biology, Karolinska Institutet, Stockholm, Sweden
}

\begin{abstract}
Human papillomavirus (HPV)-positive tonsillarand base of tongue cancer is increasing epidemically and has much better outcome than corresponding HPV-negative cancer and most other head and neck cancers with around $80 \%$ 3-year disease free survival with conventional radiotherapy and surgery. Consequently, most HPV-positive cancer patients may not require the intensified chemoradiotherapy given to many head and neck cancer patients and would, with tapered treatment, avoid several severe sideeffects. Moreover, intensified therapy has not improved survival and treatment alternatives are needed. To identify patients eligible for tapered or targeted therapy, additional biomarkers are required. Several studies have, therefore, focused on finding predictive markers, some of which are also potentially targetable. To conclude, better-tailored therapy, either as tapered or targeted, is important for increasing numbers of patients with HPV-positive tonsillarand base of tongue cancer. This review deals with some of these issues and presents some promising markers.
\end{abstract}

In 2007, human papillomavirus (HPV) was recognized as a risk factor for oropharyngeal squamous cell carcinoma (OPSCC) by the International Agency for Research against Cancer (IARC), besides the traditional risk factors smoking

This article is freely accessible online.

Correspondence to: Dr. Cinzia Bersani and Professor Tina Dalianis, Department of Oncology-Pathology, Karolinska Institutet, Cancer Center Karolinska R8:01, Karolinska University Hospital, 17176 Stockholm, Sweden. Tel: +46 851772764, e-mail: Cinzia.Bersani@ki.se and Tina.Dalianis@ki.se

Key Words: Tonsillar cancer, base of tongue cancer, oropharyngeal cancer, head and neck cancer, HPV, MHC class I, CD8+ TIL, CD44, FGFR3, VEGF-A, review. and alcohol (1-4). Concurrently, an increased incidence of OPSCC, more specifically tonsillar and base of tongue cancer (TSCC and BOTSCC, the two main HPV-positive OPSCC sites) was described in many developed countries, and found to be due to a sharp rise of HPV-positive cases (518). These HPV-positive tumors had a much better clinical outcome than their HPV-negative counterparts and head and neck squamous cell carcinoma (HNSCC) in general when treated with radiotherapy and surgery $(1-3,15-17,19,20)$. Treatment of HNSCC including OPSCC has, however, gradually become more intensified with induction chemotherapy or concurrent chemo-radiotherapy and sometimes the administration of Erbitux, leading to more severe side effects $(16,20,21)$. This is likely unnecessary for most HPV-positive TSCC and BOTSCC patients since they generally respond well to less therapy and furthermore, intensified therapy does not improve survival of HPVpositive TSCC and BOTSCC (1-3, 15-17, 20, 22, 23). It is, therefore, important to identify patients with HPV-positive TSCC and BOTSCC eligible for less treatment or targeted therapy and efforts focus now on finding predictive and targetable markers for these patients (24-39).

Here, a short background of the field and an update on recent attempts to find predictive and targetable markers with different methodologies for individualized therapy is presented.

\section{Human Papillomavirus in Tonsillar and Base of Tongue Squamous Cell Carcinoma and an Epidemic Increase of these Tumors}

In 2000, an association between HPV and OPSCC and TSCC was reported, and with radiotherapy and surgery, these HPVpositive cases had much better outcome than corresponding HPV-negative cases (80\% vs. 40-50\% 5-year survival) $(1,2)$. In 2004, a similar relationship of HPV to BOTSCC, but not to mobile tongue cancer was disclosed (40). Based on 
differing characteristics, HPV-positive and HPV-negative cancers were suggested to be separate entities, with the latter mainly caused by smoking and alcohol (1-4). Most HPVpositive tumors expressed normal p53 and overexpressed p16 ${ }^{\text {Ink4a }}$ in contrast to HPV-negative cases $(1,41)$. HPVpositive tumors were often aneuploid, less differentiated, and had, like cervical cancer, chromosome $3 \mathrm{q}$ amplification. Yet, independent of stage, differentiation, or ploidy, patients had better outcome than those with HPV-negative tumors (1-4, 42, 43). HPV-positive cancer patients were also often neversmokers, and never-smokers with HPV-positive cancer had better outcome than smokers $(22,44)$.

For HPV detection, HPV DNA and RNA analysis was done by $e . g$. PCR-based methods, in situ hybridization, and Hybrid Capture 2 assays, and $16^{\text {Ink4a }}$ overexpression by immunohistochemistry (IHC) was used as a surrogate marker for HPV (45-52). HPV E6 and E7 mRNA expression, indicative of active HPV is however the golden standard, but in formalin fixed paraffin embedded (FFPE) tissue, presence of HPV DNA with $\mathrm{p} 16^{\text {Ink4a }}$ overexpression in combination, but not each one alone, is almost as sensitive (52).

OPSCC HPV prevalence varied depending on the quality, the methodology, the time period and geographical region of the analyzed samples, but much of the variation was eventually found due to an epidemic of HPV-positive TSCC and BOTSCC in some countries (5-18).

In 2006, in Stockholm, Sweden, a rise in the incidence of TSCC was reported from 1970 to 2002 and in parallel an increase in the percentage (23\% to $68 \%$ ) of HPV-positive TSCC was found. Similar trends were subsequently described in the US (6, 8-10). Furthermore, in 2009 and 2010, reports from Sweden on TSCC and BOTSCC respectively and in 2011, from the U.S. on OPSCC showed increases of HPVpositive cases and decreases of HPV-negative cases, the latter due to reduced smoking in these countries $(11,12,17)$. Reports from some other Western countries showed similar trends $(5,7)$. The increase was eventually attributed to changes in sexual habits, and a significant correlation between HPV-positive OPSCC, early sex debut and numbers of oral or vaginal partners was reported (53).

\section{Treatment of Tonsillar and Base of Tongue Cancer}

Most TSCC and BOTSCC patients present symptoms and seek care when their tumors are fairly large similar to HNSCC in general, and they often receive the gradually intensified therapy given to other HNSCC $(16,20)$. Treatment consists of radiotherapy at high doses for 6-7 weeks and patients with advanced stage (III-IV) also have induction or concomitant chemotherapy and sometimes EGFR blockers depending on the tumor burden and whether they are medically fit $(16,20$, 21). This treatment can give acute side-effects such as pain, difficulties in swallowing and eating caused by radiation as well as nausea, mucositis and sometimes local and/or systemic infections and fatigue. Patients with remaining lymph node metastases after radiotherapy have to complete their treatment with modified neck node surgery. This can result in additional side effects, with increased fibrosis and stiffness of the neck, impaired shoulder mobility and sometimes worsening of the swallowing difficulties caused by radiotherapy. Surviving patients may suffer from late side effects e.g. xerostomia, taste alterations, difficulties with swallowing, trismus and hearing impairment that can worsen with time. Some patients suffer from radio-osteonecrosis and need reconstruction surgery (5456). Upon recurrence, patients can sometimes obtain salvage surgery or re-irradiation with or without chemotherapy. For palliative treatment, chemotherapy or biological therapies can be given $(20,21)$.

Notably, in parallel, to the intensification of HNSCC treatment, paradoxically a growing number of HPV-positive TSCC and BOTSCC patients are included in this group, of which most do not need intensified therapy, which does not even improve their survival and gives more side effects (20, 23). Clinical attempts to reduce radio- or chemotherapy are discussed and have been initiated $(57,58)$. However, to further enhance tapered or targeted therapy, improve survival and quality of life, better means to identify HPV-positive TSCC and BOTSCC patients responding well to treatment or eligible for targeted therapy are needed.

\section{Studies on Other Markers and Re-staging of HPV-positive Tonsillar and Base of Tongue Cancer and Response to Treatment}

Several approaches have been made to identify cancer patients that will respond to present therapy or need additional e.g. targeted therapy. For OPSCC, TSCC and BOTSCC, initial reports focused on differences between HPV-positive and HPV-negative tumors, while later studies investigated markers with prognostic value in other tumor types and later evaluated the use of combining these markers in mathematical models (1-3, 23-26, 28-39, 42-44, 59). More recently, next-generation sequencing (NGS), the evaluation of miRNA expression, proteomic and transcriptome profiling and the microbiome, have been explored in different tumors including HNSCC and sometimes OPSCC, TSCC and BOTSCC (37-39, 60-83). Finally, based on accumulated data, previous staging has been re-classified for HPV-positive OPSCC $(84,85)$. Below, some of these attempts are described in more detail.

\section{Studies Disclosing Differences between HPV- positive and HPV-negative Oropharyngeal Cancer, Tonsillar and Base of Tongue Cancer}

To disclose differences between HPV-positive and HPVnegative OPSCC and TSCC and follow survival, initial 
studies investigated e.g. HPV DNA/RNA status, p16 ${ }^{\text {Ink4a }}$ expression, p53 expression, age, gender, smoking, aneuploidy and comparative genomic hybridization (1-3, 22, 41-44). Non-smoking patients with tumors that were HPV DNA/RNA positive and/or overexpressed $\mathrm{p} 16^{\text {Ink4a }}$ had the best survival, while ploidy, or having specific chromosomal changes were secondary to HPV status (1-3, 22, 41-44). Physical state (episomal/integrated) and load of the viral genomes were also examined, and a high viral load was associated to better survival in some, but not all studies, while physical state had no influence on survival $(22,86,87)$.

The location of HPV in OPSCC also mattered. The prognostic significance of HPV was limited to TSCC and BOTSCC, the two subsites originating from Waldeyers lymphatic ring, while HPV was rare and its prognostic influence unclear in other OPSCC sites $(88,89)$.

Finally, using the AJCC/UICC TNM staging systems has not been useful for HPV-positive OPSCC prognostication, since already very low $\mathrm{T}$ stages often exhibited lymph node metastasis, resulting in the tumors being defined in higher stages. Therefore, a new staging system was proposed, evaluating patients with $\mathrm{p} 16^{\text {Ink4a }}$ positive and $\mathrm{p} 16^{\text {Ink4a }}$ negative OPSCC separately (84). This staging system was later validated (85) and is now included in the eighth edition of the AJCC/UICC TNM staging system manual.

\section{Studies Focusing on Immunological and Stem Cell Markers in Tonsillar and Base of Tongue Cancer}

Similar to other tumor types, immunological and other markers have often been examined by IHC in HPV-positive OPSCC, TSCC and BOTSCC (24-36). HPV-positive tumors generally had higher numbers of $\mathrm{CD}^{+}$lymphocytes infiltrating the tumor or in surrounding stroma than corresponding HPV-negative tumors, and having high numbers of $\mathrm{CD}^{+}$cells was correlated to a better survival for both HPV-positive and HPV-negative tumors (32-35). The prognostic value of $\mathrm{CD}^{+}$as well as of $\mathrm{FoxP}^{+}$lymphocytes and Cox 2 was also analyzed, but none alone correlated to survival, while having a low $\mathrm{CD} 4^{+} / \mathrm{CD}^{+}$ratio or a high $\mathrm{CD}^{+} / \mathrm{FoxP}^{+}$ratio did correlate to better survival irrespective of HPV status $(32,33)$.

Recently, the potential of PD-L1 expression as a biomarker was analyzed in parallel to that of $\mathrm{CD}^{+}$T-cells and $\mathrm{CD} 68^{+}$macrophages in HPV-positive and HPV-negative OPSCC (35). In HPV-positive tumors, high CD8 ${ }^{+}$T-cell counts indicated a good response to therapy post-radiation, while in HPV-negative tumors increased numbers of $\mathrm{CD}^{+} 8^{+}$ macrophages expressing PD-L1 may reflect a more favorable immune milieu (35).

Unexpectedly, in some but not all reports absent/low MHC class I expression was of positive prognostic value for HPV-positive TSCC and BOTSCC, whereas the reverse, as would be expected was found for those with HPVnegative cancer $(26,27)$. TAP1 and 2 , and LMP 2, 7 and 10 expression was also examined, since these factors influence peptide antigen processing and MHC class I expression (29, 30). TAP2, LMP2 and LMP7 expression frequently decreased in HPV-positive tumors, and decreased LMP7 expression and absent/low compared to medium/high nuclear LMP10 staining correlated to better survival (29, 30). MHC class II expression did not influence survival (27).

Down-regulation of MHC class I, and components of the antigen processing machinery in HPV-positive tumors could be a consequence of the strong immune defense against these tumors, necessitating a stronger need for immune escape mechanisms. The decrease in MHC class I expression was assumed to be due to active HPV infection and more specifically the downregulation of MHC class I by HPV E5 and E7 $(23,90)$. MHC class I expression was suggested to increase upon irradiation and make the tumors more sensitive to the immune system of the host (91). Indeed, experimentally, irradiation increased MHC class I expression in vitro in some, but not all, HPV-positive OPSCC cell lines and in one HPV-positive cell line a decrease in HPV16 E5 mRNA expression was also noted (91). Increased MHC class I expression upon irradiation could in part explain why HPV-positive tumors with absent/low MHC class I expression still respond readily to therapy and are recognized by the immune system (91). Eliciting a vigorous immune response in this context, would be in line with data obtained in mice, where HPV-positive tumors were curable after cisplatin or radiation therapy only in immunocompetent and not in immunoincompetent mice (92). In that system, it was proposed that being able to mount an immune response was required to eradicate these tumors (92).

The role of HPV mRNA expression was also analyzed in correlation to survival, due to a possible correlation to $\mathrm{MHC}$ class I expression (90). The presence of HPV16 E2, E5 or E7 mRNA did not correlate to MHC class I expression. However, the absence of HPV16 E2 mRNA correlated with worse prognosis similarly to cervical cancer $(23,90)$.

Other molecular markers studied by IHC were CD44 and CD98, and having low CD44 intensity expression or CD98 expression was beneficial for survival for patients with HPVpositive and HPV-negative cancer (31) For tumor suppressor genes LRIG 1-3, only high expression of LRIG1 was correlated to better survival in HPV-positive, but not HPVnegative TSCC and BOTSCC (36).

Taken together the immunological and IHC analysis show that some markers could be specific for only HPV-positive OPSCC, TSCC and BOTSCC, or HPV-negative OPSCC, while others could be of more general use. 


\section{Sequencing of Head and Neck Cancer, Oropharyngeal, Tonsillar and Base of Tongue Cancer and the Unraveling of Additional Differences Between HPV-positive and HPV-negative Cancers and Targetable Markers}

The application of next-generation sequencing (NGS) technology for mutational analysis of tumors for clinical and research purposes has increased exponentially the past 10 years, thanks to reasonable costs and the extremely small amount of DNA needed (even from low-quality FFPEderived DNA).

The NGS approach to HNSCC has revealed some distinct differences between HPV-positive and HPV-negative tumors and is providing valuable additional information on HPV affected genes and on potential therapeutic targets for HNSCC patients (37-39, 60-64). More specifically, HPVpositive OPSCC, mostly TSCC and BOTSCC, show increased mutation rates in PIK3CA, NOTCH1 and the fibroblast growth factor 3 (FGFR3), while HPV-negative tumors are dominated by mutations in TP53 and $C D K N 2 \mathrm{~A} / \mathrm{B}$ and to a lower degree in PIK3CA (37-39, 60-64).

Mutated TP53 was found to be of prognostic value for survival in HPV-negative OPSCC in one, but not in another study $(38,39)$. This discrepancy might be due to differences in sequencing methods, classification of TP53 mutation as well as number and type of patients included in the analysis (38, 39). PRIMA-1 $1^{M E T}$ is the only drug currently under clinical trials targeting mutant $p 53$ (93). Mutation in PIK3CA gene has also been associated with poorer prognosis in human cancer (9496). However, no conclusive data are reported for HNSCC (66, 97). Nevertheless, a relevant number of inhibitors targeting PIK3CA or the PI3K pathway are available and on trial (98).

Another gene of interest, FGFR3, is often mutated in HPV-positive HNSCC (7-11\%) compared to HPV-negative HNSCC (2\%) and represents an interesting therapeutic target since specific inhibitors are available $(39,60,64)$. Furthermore, the FGFR 3 p.S249C variant has been primarily found in HPV-positive OPSCC and cervical cancer and has been associated with poorer prognosis $(39,60,98-100)$. Targeted therapy with FGFR inhibitors has shown promising therapeutic effect in pre-clinical and clinical studies (101$105)$ and this applies also to the FGFR3-TACC 3 translocation found in HPV-positive HNSCC (105).

To summarize, gene sequencing is disclosing both new and already known mutations in HPV-positive and HPVnegative tumors, where targeted therapy could be available.

\section{MicroRNA Expression in Oropharyngeal Cancer in Relation to HPV-status and Clinical Outcome}

MicroRNA (miR) expression in OPSCC has been mainly analyzed in normal tissue, HPV-positive vs. HPV-negative tumor status and to a lesser extent to outcome (67-73). The results varied, with many miRs proposed to correlate with tumor HPV status or outcome, with few miRs found common between studies. Mir-9, 155 and 163b were in several studies found overexpressed in HPV-positive $v s$. HPV-negative OPSCC, while miR-31 and 193b were downregulated $(68-71,73)$. Also, a $25 \mathrm{miR}$ signature discriminating HPV-positive $v s$. HPV-negative OPSCC was suggested, but few of the indicated miRs were common with other studies (67). These discrepancies can depend on the assessment of large miR numbers in small sample sizes and lack of validation cohorts.

Few studies have analyzed miR expression in OPSCC in relation both to HPV and clinical outcome and these miRs differ between the studies (71-73). Overexpression of miR$142-3 p, 146 a, 26 b$ was positively correlated to overall survival, while miR-31,24, 193b was negatively correlated in a study by Gao et al. (73). In another study on clinical outcome in relation to different chemo-radiotherapy combinations, miR-146a, 155, 200b were correlated to treatment outcome, with the first two independent of tumor HPV status (72).

To summarize, there are still limited numbers of studies relating miR expression to clinical outcome of OPSCC and in relation to tumor HPV status. Given the large variation in miRs found, more studies on large cohorts, including validation sets, are needed before miRs can be used in the clinical practice for prediction of clinical outcome.

\section{Transcriptome Analysis in OPSCC}

Some studies have described differences between HPVpositive and HPV-negative OPSCC with regard to RNA expression and differences have mainly been reported in genes involved in immune response, apoptosis, proliferation/ cell cycle and differentiation $(74-77,106)$. Notably, some studies have, based on transcriptional and HPV data, suggested molecular sub-grouping of HNSCC. Two distinct subtypes were e.g. described among HPV-positive tumors and these had different clinical outcomes, suggesting heterogeneity among the HPV-positive tumors (77). Moreover, genes related to immune defense, e.g. CD8a, have also been linked to HPV status and better survival by transcriptional analysis (78).

\section{Protein Profiling in Oropharyngeal Cancer}

While several studies have analyzed differences in mRNA expression between HPV-positive and HPV-negative OPSCC, few proteomic analyses have been performed. Sewell et al. used reverse-phase protein array profiling on a restricted set of 137 total and phosphorylated proteins (66). Differences were found in e.g. PI3K/AKT/mTOR and 
receptor kinase pathways. Protein expression was also evaluated in relation to PIK3CA mutations in HPV-positive OPSCC and found to be associated with activation of mTOR. Another study presented proteomic profiling by mass spectrometry and described differences between HPVpositive and HPV-negative OPSCC in a large number of pathways and a specific finding was the increased expression of ASS1 in HPV-positive OPSCC (65).

\section{Microbiome Studies in Head and Neck Cancer}

Recently the human microbiome has been established to connect functionally to diseases such as cancers, enteric infectious diseases, aging, obesity, diabetes and neurological disorders $(79,80)$. Although not as well characterized as in the gut, a growing body of evidence hints that the microbiota in the oral tracts also plays a role in modulating our health and $e . g$. changes in abundance of Firmicutes (Streptococcus) have been suggested to be associated with oral pre-cancers (81). Recently, a study on HNSCC patients showed a significant loss in diversity of microbiota species compared with healthy controls (82). In addition, bacteria diversity also significantly decreased after surgery (83). Furthermore, it has been noted that mucosal toxicity of different treatments for HNSCC are related to patient overall survival, also including HPV status in the analysis (107). If microbiome or related metabolic changes after therapy are related to the mucosal toxicity shift is of interest to evaluate further. So far, research on microbiome changes associated to HPV infection in HNSCC is limited, but HPV infection has been associated with microbiota changes in HPV related cervical intraepithelial neoplasia (CIN) and cervical cancer (108). There is hint that the abundance of Veillonella, Prevotela and Streptococcus fluctuated when HPV status changed (83). However, all data in HNSCC are still preliminary and the sample sizes are small. More investments are urgently needed before one can apply bacteria such as probiotic Lactobacillus into HNSCC prevention and treatments. Together these results suggest that HNSCC associated shifts in the composition of the microbial community may provide us another possible explanation for HNSCC cancer progression.

\section{Conclusion}

HPV-positive TSCC and BOTSCC have much better outcome than corresponding HPV-negative cases and have been increasing epidemically in incidence the past decades. Individualizing treatment for this group of patients is important and many attempts in finding markers useful for tapering or targeting treatment are being made of which some are successful. Hopefully in the future, many of these patients will benefit from some of these efforts.

\section{Conflicts of Interest}

No conflicts of interests declared.

\section{Acknowledgements}

This work was supported in part by the Swedish Cancer Foundation, the Stockholm Cancer Society, the Cancer and Allergy Foundation, Svenska Läkarsällskapet (SLS), Magnus Bergvalls stiftelse, stiftelsen Tornspiran, the Stockholm City Council, the Sigurd and Elsa Goljes Foundation and the Karolinska Institutet, Sweden.

\section{References}

1 Gillison ML, Koch WM, Capone RB, Spafford M, Westra WH, Wu L, Zahurak ML, Daniel RW, Viglione M, Symer DE, Shah KV and Sidransky D: Evidence for a causal association between human papillomavirus and a subset of head and neck cancers. J Natl Cancer Inst 92: 709-720, 2000.

2 Mellin H, Friesland S, Lewensohn R, Dalianis T and MunckWikland E: Human papillomavirus (HPV) DNA in tonsillar cancer: clinical correlates, risk of relapse, and survival. Int $\mathrm{J}$ Cancer 89: 300-304, 2000.

3 Dahlstrand HM and Dalianis T: Presence and influence of human papillomaviruses (HPV) in Tonsillar cancer. Adv Cancer Res 93: 59-89, 2005.

4 WHO: IARC Monographs on the Evaluation of carcinogenic risk to humans. Lyon, France: International Agency for Research on Cancer, 2007.

5 Robinson KL and Macfarlane GJ: Oropharyngeal cancer incidence and mortality in Scotland: are rates still increasing? Oral Oncol 39: 31-36, 2003.

6 Hammarstedt L, Lindquist D, Dahlstrand H, Romanitan M, Dahlgren LO, Joneberg J, Creson N, Lindholm J, Ye W, Dalianis T and Munck-Wikland E: Human papillomavirus as a risk factor for the increase in incidence of tonsillar cancer. Int J Cancer 119: 2620-2623, 2006.

7 Conway DI, Stockton DL, Warnakulasuriya KA, Ogden G and Macpherson LM: Incidence of oral and oropharyngeal cancer in United Kingdom (1990-1999) - recent trends and regional variation. Oral Oncol 42: 586-592, 2006.

8 Hammarstedt L, Dahlstrand H, Lindquist D, Onelov L, Ryott M, Luo J, Dalianis T, Ye W and Munck-Wikland E: The incidence of tonsillar cancer in Sweden is increasing. Acta Otolaryngol 127: 988-992, 2007.

9 Sturgis EM and Cinciripini PM: Trends in head and neck cancer incidence in relation to smoking prevalence: an emerging epidemic of human papillomavirus-associated cancers? Cancer 110: 1429-1435, 2007.

10 Chaturvedi AK, Engels EA, Anderson WF and Gillison ML: Incidence trends for human papillomavirus-related and unrelated oral squamous cell carcinomas in the United States. J Clin Oncol 26: 612-619, 2008.

11 Nasman A, Attner P, Hammarstedt L, Du J, Eriksson M, Giraud G, Ahrlund-Richter S, Marklund L, Romanitan M, Lindquist D, Ramqvist T, Lindholm J, Sparen P, Ye W, Dahlstrand H, Munck-Wikland $\mathrm{E}$ and Dalianis $\mathrm{T}$ : Incidence of human papillomavirus (HPV) positive tonsillar carcinoma in Stockholm, Sweden: an epidemic of viral-induced carcinoma? Int J Cancer 125: 362-366, 2009. 
12 Braakhuis BJ, Visser $\mathrm{O}$ and Leemans $\mathrm{CR}$ : Oral and oropharyngeal cancer in The Netherlands between 1989 and 2006: Increasing incidence, but not in young adults. Oral Oncol 45: e85-89, 2009.

13 Attner P, Du J, Nasman A, Hammarstedt L, Ramqvist T, Lindholm J, Marklund L, Dalianis T and Munck-Wikland E: The role of human papillomavirus in the increased incidence of base of tongue cancer. Int J Cancer 126: 2879-2884, 2010.

14 Marur S, D'Souza G, Westra WH and Forastiere AA: HPVassociated head and neck cancer: a virus-related cancer epidemic. Lancet Oncol 11: 781-789, 2010.

15 Ramqvist T and Dalianis T: Oropharyngeal cancer epidemic and human papillomavirus. Emerg Infect Dis 16: 1671-1677, 2010.

16 Ramqvist $\mathrm{T}$ and Dalianis $\mathrm{T}$ : An epidemic of oropharyngeal squamous cell carcinoma (OSCC) due to human papillomavirus (HPV) infection and aspects of treatment and prevention. Anticancer Res 31: 1515-1519, 2011.

17 Chaturvedi AK, Engels EA, Pfeiffer RM, Hernandez BY, Xiao W, Kim E, Jiang B, Goodman MT, Sibug-Saber M, Cozen W, Liu L, Lynch CF, Wentzensen N, Jordan RC, Altekruse S, Anderson WF, Rosenberg PS and Gillison ML: Human papillomavirus and rising oropharyngeal cancer incidence in the United States. J Clin Oncol 29: 4294-4301, 2011.

18 Nasman A, Nordfors C, Holzhauser S, Vlastos A, Tertipis N, Hammar U, Hammarstedt-Nordenvall L, Marklund L, MunckWikland E, Ramqvist T, Bottai M and Dalianis T: Incidence of human papillomavirus positive tonsillar and base of tongue carcinoma: a stabilisation of an epidemic of viral induced carcinoma? Eur J Cancer 51: 55-61, 2015.

19 Attner P, Du J, Nasman A, Hammarstedt L, Ramqvist T, Lindholm J, Marklund L, Dalianis T and Munck-Wikland E: Human papillomavirus and survival in patients with base of tongue cancer. Int J Cancer 128: 2892-2897, 2011.

20 Licitra L, Bernier J, Grandi C, Merlano M, Bruzzi P and Lefebvre JL: Cancer of the oropharynx. Crit Rev Oncol Hematol 41: 107-122, 2002.

21 Chen AY, Zhu J and Fedewa S: Temporal trends in oropharyngeal cancer treatment and survival: 1998-2009. The Laryngoscope 124: 131-138, 2014.

22 Lindquist D, Romanitan M, Hammarstedt L, Nasman A, Dahlstrand H, Lindholm J, Onelov L, Ramqvist T, Ye W, Munck-Wikland E and Dalianis T: Human papillomavirus is a favourable prognostic factor in tonsillar cancer and its oncogenic role is supported by the expression of E6 and E7. Mol Oncol 1: 350-355, 2007.

23 Bersani C, Mints M, Tertipis N, Haeggblom L, Sivars L, Ahrlund-Richter A, Vlastos A, Smedberg C, Grun N, MunckWikland E, Nasman A, Ramqvist T and Dalianis T: A model using concomitant markers for predicting outcome in human papillomavirus positive oropharyngeal cancer. Oral Oncol 68: 53-59, 2017.

24 Lindquist D, Ahrlund-Richter A, Tarjan M, Tot T and Dalianis $\mathrm{T}$ : Intense CD44 expression is a negative prognostic factor in tonsillar and base of tongue cancer. Anticancer Res 32: 153$161,2012$.

25 Nasman A, Nordfors C, Grun N, Munck-Wikland E, Ramqvist T, Marklund L, Lindquist D and Dalianis T: Absent/weak CD44 intensity and positive human papillomavirus (HPV) status in oropharyngeal squamous cell carcinoma indicates a very high survival. Cancer medicine 2: 507-518, 2013.
26 Nasman A, Andersson E, Nordfors C, Grun N, Johansson H, Munck-Wikland E, Massucci G, Dalianis T and Ramqvist T: MHC class I expression in HPV positive and negative tonsillar squamous cell carcinoma in correlation to clinical outcome. Int J Cancer 132: 72-81, 2013.

27 Nasman A, Andersson E, Marklund L, Tertipis N, Hammarstedt-Nordenvall L, Attner P, Nyberg T, Masucci GV, Munck-Wikland E, Ramqvist T and Dalianis T: HLA class I and II expression in oropharyngeal squamous cell carcinoma in relation to tumor HPV status and clinical outcome. PLoS One 8: e77025, 2013.

28 Tertipis N, Villabona L, Nordfors C, Nasman A, Ramqvist T, Vlastos A, Masucci G and Dalianis T: HLA-A*02 in relation to outcome in human papillomavirus positive tonsillar and base of tongue cancer. Anticancer Res 34: 2369-2375, 2014.

29 Tertipis N, Haeggblom L, Nordfors C, Grun N, Nasman A, Vlastos A, Dalianis T and Ramqvist T: Correlation of LMP10 expression and clinical outcome in Human Papillomavirus (HPV) positive and HPV-Negative tonsillar and base of tongue cancer. PLoS One 9: e95624, 2014.

30 Tertipis N, Haeggblom L, Grun N, Nordfors C, Nasman A, Dalianis $\mathrm{T}$ and Ramqvist $\mathrm{T}$ : Reduced Expression of the Antigen Processing Machinery Components TAP2, LMP2, and LMP7 in Tonsillar and Base of Tongue Cancer and Implications for Clinical Outcome. Transl Oncol 8: 10-17, 2015.

31 Rietbergen MM, Martens-de Kemp SR, Bloemena E, Witte BI, Brink A, Baatenburg de Jong RJ, Leemans CR, Braakhuis BJ and Brakenhoff RH: Cancer stem cell enrichment marker CD98: a prognostic factor for survival in patients with human papillomavirus-positive oropharyngeal cancer. Eur J Cancer 50: 765-773, 2014.

32 Nasman A, Romanitan M, Nordfors C, Grun N, Johansson H, Hammarstedt L, Marklund L, Munck-Wikland E, Dalianis T and Ramqvist T: Tumor infiltrating $\mathrm{CD}^{+}$and Foxp3+ lymphocytes correlate to clinical outcome and human papillomavirus (HPV) status in tonsillar cancer. PLoS One 7: e38711, 2012.

33 Nordfors C, Grun N, Tertipis N, Ahrlund-Richter A, Haeggblom L, Sivars L, Du J, Nyberg T, Marklund L, Munck-Wikland E, Nasman A, Ramqvist T and Dalianis T: $\mathrm{CD}^{+}$and $\mathrm{CD} 4^{+}$tumour infiltrating lymphocytes in relation to human papillomavirus status and clinical outcome in tonsillar and base of tongue squamous cell carcinoma. Eur J Cancer 49: 2522-2530, 2013.

34 Oguejiofor K, Hall J, Slater C, Betts G, Hall G, Slevin N, Dovedi S, Stern PL and West CM: Stromal infiltration of CD8 $\mathrm{T}$ cells is associated with improved clinical outcome in HPVpositive oropharyngeal squamous carcinoma. Br J Cancer 113: 886-893, 2015.

35 Oguejiofor K, Galletta-Williams H, Dovedi SJ, Roberts DL, Stern PL and West CM: Distinct patterns of infiltrating CD8+ $\mathrm{T}$ cells in $\mathrm{HPV}^{+}$and $\mathrm{CD} 68$ macrophages in HPVoropharyngeal squamous cell carcinomas are associated with better clinical outcome but PD-L1 expression is not prognostic. Oncotarget 8: 14416-14427, 2017.

36 Lindquist D, Nasman A, Tarjan M, Henriksson R, Tot T, Dalianis T and Hedman H: Expression of LRIG1 is associated with good prognosis and human papillomavirus status in oropharyngeal cancer. Br J Cancer 110: 1793-1800, 2014.

37 Lechner M, Frampton GM, Fenton T, Feber A, Palmer G, Jay A, Pillay N, Forster M, Cronin MT, Lipson D, Miller VA, 
Brennan TA, Henderson S, Vaz F, O'Flynn P, Kalavrezos N Yelensky R, Beck S, Stephens PJ and Boshoff C: Targeted nextgeneration sequencing of head and neck squamous cell carcinoma identifies novel genetic alterations in HPV+ and HPV- tumors. Genome Med 5: 49, 2013.

38 Tinhofer I, Budach V, Saki M, Konschak R, Niehr F, Johrens K, Weichert W, Linge A, Lohaus F, Krause M, Neumann K, Endris V, Sak A, Stuschke M, Balermpas P, Rodel C, Avlar M, Grosu AL, Abdollahi A, Debus J, Belka C, Pigorsch S, Combs SE, Monnich D, Zips D, Baumann M and Dktk ROG: Targeted next-generation sequencing of locally advanced squamous cell carcinomas of the head and neck reveals druggable targets for improving adjuvant chemoradiation. Eur J Cancer 57: 78-86, 2016.

39 Bersani C, Sivars L, Haeggblom L, DiLorenzo S, Mints M, Ahrlund-Richter A, Tertipis N, Munck-Wikland E, Nasman A, Ramqvist $\mathrm{T}$ and Dalianis $\mathrm{T}$ : Targeted sequencing of tonsillar and base of tongue cancer and human papillomavirus positive unknown primary of the head and neck reveals prognostic effects of mutated FGFR3. Oncotarget 8: 35339-35350, 2017.

40 Dahlgren L, Dahlstrand HM, Lindquist D, Hogmo A, Bjornestal L, Lindholm J, Lundberg B, Dalianis T and Munck-Wikland E: Human papillomavirus is more common in base of tongue than in mobile tongue cancer and is a favorable prognostic factor in base of tongue cancer patients. Int J Cancer 112: 1015-1019, 2004.

41 Mellin Dahlstrand H, Lindquist D, Bjornestal L, Ohlsson A, Dalianis T, Munck-Wikland E and Elmberger G: P16(INK4a) correlates to human papillomavirus presence, response to radiotherapy and clinical outcome in tonsillar carcinoma. Anticancer Res 25: 4375-4383, 2005.

42 Mellin H, Friesland S, Auer G, Dalianis T and Munck-Wikland E: Human papillomavirus and DNA ploidy in tonsillar cancer-correlation to prognosis. Anticancer Res 23: 2821-2828, 2003.

43 Dahlgren L, Mellin H, Wangsa D, Heselmeyer-Haddad K, Bjornestal L, Lindholm J, Munck-Wikland E, Auer G, Ried T and Dalianis T: Comparative genomic hybridization analysis of tonsillar cancer reveals a different pattern of genomic imbalances in human papillomavirus-positive and -negative tumors. Int J Cancer 107: 244-249, 2003.

44 Ang KK, Harris J, Wheeler R, Weber R, Rosenthal DI, NguyenTan PF, Westra WH, Chung CH, Jordan RC, Lu C, Kim H, Axelrod R, Silverman CC, Redmond KP and Gillison ML: Human papillomavirus and survival of patients with oropharyngeal cancer. The New England journal of medicine 363: 24-35, 2010.

45 Oguejiofor KK, Hall JS, Mani N, Douglas C, Slevin NJ, Homer $\mathrm{J}$, Hall $\mathrm{G}$ and West CM: The prognostic significance of the biomarker p16 in oropharyngeal squamous cell carcinoma. Clin Oncol (R Coll Radiol) 25: 630-638, 2013.

46 de Roda Husman AM, Walboomers JM, van den Brule AJ, Meijer CJ and Snijders PJ: The use of general primers GP5 and GP6 elongated at their 3' ends with adjacent highly conserved sequences improves human papillomavirus detection by PCR. J Gen Virol 76(Pt 4): 1057-1062, 1995.

47 Tieben LM, ter Schegget J, Minnaar RP, Bouwes Bavinck JN, Berkhout RJ, Vermeer BJ, Jebbink MF and Smits HL: Detection of cutaneous and genital HPV types in clinical samples by PCR using consensus primers. Journal of virological methods 42: 265-279, 1993
48 van den Brule AJ, Pol R, Fransen-Daalmeijer N, Schouls LM, Meijer CJ and Snijders PJ: GP5+/6+ PCR followed by reverse line blot analysis enables rapid and high-throughput identification of human papillomavirus genotypes. J Clin Microbiol 40: 779-787, 2002.

49 Clavel C, Masure M, Bory JP, Putaud I, Mangeonjean C, Lorenzato M, Gabriel R, Quereux C and Birembaut P: Hybrid Capture II-based human papillomavirus detection, a sensitive test to detect in routine high-grade cervical lesions: a preliminary study on 1518 women. Br J Cancer 80: 1306-1311, 1999.

50 Gravitt PE, Peyton CL, Apple RJ and Wheeler CM: Genotyping of 27 human papillomavirus types by using L1 consensus PCR products by a single-hybridization, reverse line blot detection method. J Clin Microbiol 36: 3020-3027, 1998.

51 Schmitt M, Bravo IG, Snijders PJ, Gissmann L, Pawlita M and Waterboer T: Bead-based multiplex genotyping of human papillomaviruses. J Clin Microbiol 44: 504-512, 2006.

52 Smeets SJ, Hesselink AT, Speel EJ, Haesevoets A, Snijders PJ, Pawlita M, Meijer CJ, Braakhuis BJ, Leemans CR and Brakenhoff RH: A novel algorithm for reliable detection of human papillomavirus in paraffin embedded head and neck cancer specimen. Int J Cancer 121: 2465-2472, 2007.

53 D'Souza G, Kreimer AR, Viscidi R, Pawlita M, Fakhry C, Koch WM, Westra WH and Gillison ML: Case-control study of human papillomavirus and oropharyngeal cancer. The New England journal of medicine 356: 1944-1956, 2007.

54 Kraaijenga SA, Oskam IM, van Son RJ, Hamming-Vrieze O, Hilgers FJ, van den Brekel MW and van der Molen L: Assessment of voice, speech, and related quality of life in advanced head and neck cancer patients 10-years+ after chemoradiotherapy. Oral Oncol 55: 24-30, 2016.

55 Loorents V, Rosell J, Salgado Willner H, and Borjeson S: Health-related quality of life up to 1 year after radiotherapy in patients with head and neck cancer (HNC). Springerplus 5: 669, 2016.

56 Wan Leung S, Lee TF, Chien CY, Chao PJ, Tsai WL and Fang FM: Health-related quality of life in 640 head and neck cancer survivors after radiotherapy using EORTC QLQ-C30 and QLQH\&N35 questionnaires. BMC Cancer 11: 128, 2011.

57 Masterson L, Moualed D, Liu ZW, Howard JE, Dwivedi RC, Tysome JR, Benson R, Sterling JC, Sudhoff H, Jani P and Goon PK: De-escalation treatment protocols for human papillomavirusassociated oropharyngeal squamous cell carcinoma: a systematic review and meta-analysis of current clinical trials. Eur J Cancer 50: 2636-2648, 2014.

58 Mehanna H: Update on De-intensification and Intensification Studies in HPV. Recent Results Cancer Res 206: 251-256, 2017.

59 Tertipis N, Hammar U, Nasman A, Vlastos A, Nordfors C, Grun N, Ahrlund-Richter A, Sivars L, Haeggblom L, Marklund L, Hammarstedt-Nordenvall L, Chaturvedi AK, Munck-Wikland E, Ramqvist T, Bottai M and Dalianis T: A model for predicting clinical outcome in patients with human papillomavirus-positive tonsillar and base of tongue cancer. Eur J Cancer 51: 15801587, 2015.

60 Seiwert TY, Zuo Z, Keck MK, Khattri A, Pedamallu CS, Stricker T, Brown C, Pugh TJ, Stojanov P, Cho J, Lawrence MS, Getz G, Bragelmann J, DeBoer R, Weichselbaum RR, Langerman A, Portugal L, Blair E, Stenson K, Lingen MW, Cohen EE, Vokes EE, White KP and Hammerman PS: Integrative and comparative genomic analysis of HPV-positive 
and HPV-negative head and neck squamous cell carcinomas. Clin Cancer Res 21: 632-641, 2015.

61 Rusan M, Li YY and Hammerman PS: Genomic landscape of human papillomavirus-associated cancers. Clin Cancer Res 21: 2009-2019, 2015.

62 Gaykalova DA, Mambo E, Choudhary A, Houghton J, Buddavarapu K, Sanford T, Darden W, Adai A, Hadd A, Latham G, Danilova LV, Bishop J, Li RJ, Westra WH, Hennessey P, Koch WM, Ochs MF, Califano JA and Sun W: Novel insight into mutational landscape of head and neck squamous cell carcinoma. PLoS One 9: e93102, 2014.

63 Chung CH, Guthrie VB, Masica DL, Tokheim C, Kang H, Richmon J, Agrawal N, Fakhry C, Quon H, Subramaniam RM, Zuo Z, Seiwert T, Chalmers ZR, Frampton GM, Ali SM, Yelensky R, Stephens PJ, Miller VA, Karchin R and Bishop JA: Genomic alterations in head and neck squamous cell carcinoma determined by cancer gene-targeted sequencing. Ann Oncol 26: 1216-1223, 2015.

64 Cancer Genome Atlas N: Comprehensive genomic characterization of head and neck squamous cell carcinomas. Nature 517: 576-582, 2015.

65 Slebos RJ, Jehmlich N, Brown B, Yin Z, Chung CH, Yarbrough WG and Liebler DC: Proteomic analysis of oropharyngeal carcinomas reveals novel HPV-associated biological pathways. Int J Cancer 132: 568-579, 2013.

66 Sewell A, Brown B, Biktasova A, Mills GB, Lu Y, Tyson DR, Issaeva $\mathrm{N}$ and Yarbrough WG: Reverse-phase protein array profiling of oropharyngeal cancer and significance of PIK3CA mutations in HPV-associated head and neck cancer. Clin Cancer Res 20: 2300-2311, 2014.

67 Mirghani H, Ugolin N, Ory C, Goislard M, Lefevre M, Baulande S, Hofman P, Guily JL, Chevillard S and Lacave R: Comparative analysis of micro-RNAs in human papillomaviruspositive versus -negative oropharyngeal cancers. Head \& neck 38: 1634-1642, 2016.

68 Miller DL, Davis JW, Taylor KH, Johnson J, Shi Z, Williams R, Atasoy U, Lewis JS, Jr. and Stack MS: Identification of a human papillomavirus-associated oncogenic miRNA panel in human oropharyngeal squamous cell carcinoma validated by bioinformatics analysis of the Cancer Genome Atlas. Am J Pathol 185: 679-692, 2015.

69 Lajer CB, Nielsen FC, Friis-Hansen L, Norrild B, Borup R, Garnaes E, Rossing M, Specht L, Therkildsen MH, Nauntofte B, Dabelsteen S and von Buchwald C: Different miRNA signatures of oral and pharyngeal squamous cell carcinomas: a prospective translational study. Br J Cancer 104: 830-840, 2011.

70 Lajer CB, Garnaes E, Friis-Hansen L, Norrild B, Therkildsen MH, Glud M, Rossing M, Lajer H, Svane D, Skotte L, Specht L, Buchwald C and Nielsen FC: The role of miRNAs in human papilloma virus (HPV)-associated cancers: bridging between HPV-related head and neck cancer and cervical cancer. Br J Cancer 106: 1526-1534, 2012.

71 Hui AB, Lin A, Xu W, Waldron L, Perez-Ordonez B, Weinreb I, Shi W, Bruce J, Huang SH, O'Sullivan B, Waldron J, Gullane P, Irish JC, Chan K and Liu FF: Potentially prognostic miRNAs in HPV-associated oropharyngeal carcinoma. Clin Cancer Res 19: 2154-2162, 2013.

72 Hess AK, Muer A, Mairinger FD, Weichert W, Stenzinger A, Hummel M, Budach V and Tinhofer I: MiR-200b and miR-155 as predictive biomarkers for the efficacy of chemoradiation in locally advanced head and neck squamous cell carcinoma. Eur J Cancer 77: 3-12, 2017.

73 Gao G, Gay HA, Chernock RD, Zhang TR, Luo J, Thorstad WL, Lewis JS Jr. and Wang X: A microRNA expression signature for the prognosis of oropharyngeal squamous cell carcinoma. Cancer 119: 72-80, 2013.

74 Mirghani H, Ugolin N, Ory C, Lefevre M, Baulande S, Hofman P, St Guily JL, Chevillard S and Lacave R: A predictive transcriptomic signature of oropharyngeal cancer according to HPV16 status exclusively. Oral Oncol 50: 1025-1034, 2014.

75 Martinez I, Wang J, Hobson KF, Ferris RL and Khan SA: Identification of differentially expressed genes in HPV-positive and HPV-negative oropharyngeal squamous cell carcinomas. Eur J Cancer 43: 415-432, 2007.

76 Wichmann G, Rosolowski M, Krohn K, Kreuz M, Boehm A, Reiche A, Scharrer U, Halama D, Bertolini J, Bauer U, Holzinger D, Pawlita M, Hess J, Engel C, Hasenclever D, Scholz M, Ahnert P, Kirsten H, Hemprich A, Wittekind C, Herbarth O, Horn F, Dietz A, Loeffler M, Leipzig H and Neck G: The role of HPV RNA transcription, immune responserelated gene expression and disruptive TP53 mutations in diagnostic and prognostic profiling of head and neck cancer. Int J Cancer 137: 2846-2857, 2015.

77 Keck MK, Zuo Z, Khattri A, Stricker TP, Brown CD, Imanguli M, Rieke D, Endhardt K, Fang P, Bragelmann J, DeBoer R, ElDinali M, Aktolga S, Lei Z, Tan P, Rozen SG, Salgia R, Weichselbaum RR, Lingen MW, Story MD, Ang KK, Cohen EE, White KP, Vokes EE and Seiwert TY: Integrative analysis of head and neck cancer identifies two biologically distinct HPV and three non-HPV subtypes. Clin Cancer Res 21: 870$881,2015$.

78 Jung AC, Guihard S, Krugell S, Ledrappier S, Brochot A, Dalstein V, Job S, de Reynies A, Noel G, Wasylyk B, Clavel C and Abecassis J: CD8-alpha T-cell infiltration in human papillomavirus-related oropharyngeal carcinoma correlates with improved patient prognosis. Int J Cancer 132: E26-36, 2013.

79 Clemente JC, Ursell LK, Parfrey LW, and Knight R: The impact of the gut microbiota on human health: an integrative view. Cell 148: 1258-1270, 2012.

80 Garrett WS: Cancer and the microbiota. Science 348: 80-86, 2015.

81 Wade WG: The oral microbiome in health and disease. Pharmacol Res 69: 137-143, 2013.

82 Schmidt BL, Kuczynski J, Bhattacharya A, Huey B, Corby PM, Queiroz EL, Nightingale K, Kerr AR, DeLacure MD, Veeramachaneni R, Olshen AB, Albertson DG and Muy-Teck $\mathrm{T}$ : Changes in abundance of oral microbiota associated with oral cancer. PLoS One 9: e98741, 2014.

83 Guerrero-Preston R, Godoy-Vitorino F, Jedlicka A, RodriguezHilario A, Gonzalez H, Bondy J, Lawson F, Folawiyo O, Michailidi C, Dziedzic A, Thangavel R, Hadar T, Noordhuis MG, Westra W, Koch W and Sidransky D: 16S rRNA amplicon sequencing identifies microbiota associated with oral cancer, human papilloma virus infection and surgical treatment. Oncotarget 7: 51320-51334, 2016.

84 Huang SH, Xu W, Waldron J, Siu L, Shen X, Tong L, Ringash J, Bayley A, Kim J, Hope A, Cho J, Giuliani M, Hansen A, Irish J, Gilbert R, Gullane P, Perez-Ordonez B, Weinreb I, Liu FF and O'Sullivan B: Refining American Joint Committee on Cancer/Union for International Cancer Control TNM stage and 
prognostic groups for human papillomavirus-related oropharyngeal carcinomas. J Clin Oncol 33: 836-845, 2015.

85 O'Sullivan B, Huang SH, Su J, Garden AS, Sturgis EM, Dahlstrom K, Lee N, Riaz N, Pei X, Koyfman SA, Adelstein D, Burkey BB, Friborg J, Kristensen CA, Gothelf AB, Hoebers F, Kremer B, Speel EJ, Bowles DW, Raben D, Karam SD, Yu $\mathrm{E}$ and $\mathrm{Xu}$ W: Development and validation of a staging system for HPV-related oropharyngeal cancer by the International Collaboration on Oropharyngeal cancer Network for Staging (ICON-S): a multicentre cohort study. Lancet Oncol 17: 440451, 2016.

86 Mellin H, Dahlgren L, Munck-Wikland E, Lindholm J, Rabbani $\mathrm{H}$, Kalantari M and Dalianis T: Human papillomavirus type 16 is episomal and a high viral load may be correlated to better prognosis in tonsillar cancer. Int J Cancer 102: 152-158, 2002.

87 Koskinen WJ, Chen RW, Leivo I, Makitie A, Back L, Kontio R, Suuronen R, Lindqvist C, Auvinen E, Molijn A, Quint WG, Vaheri A and Aaltonen LM: Prevalence and physical status of human papillomavirus in squamous cell carcinomas of the head and neck. Int J Cancer 107: 401-406, 2003.

88 Marklund L, Nasman A, Ramqvist T, Dalianis T, MunckWikland E and Hammarstedt L: Prevalence of human papillomavirus and survival in oropharyngeal cancer other than tonsil or base of tongue cancer. Cancer medicine 1: 82-88, 2012.

89 Haeggblom L, Ramqvist T, Tommasino M, Dalianis T and Näsman A: Time to change perspectives on HPV in oropharyngeal cancer. A systematic review of HPV prevalence per oropharyngeal sub-site the last 3 years. Papillomavirus Res 4: 1-11, 2017.

90 Ramqvist T, Mints M, Tertipis N, Nasman A, Romanitan M and Dalianis T: Studies on human papillomavirus (HPV) 16 E2, E5 and E7 mRNA in HPV-positive tonsillar and base of tongue cancer in relation to clinical outcome and immunological parameters. Oral Oncol 51: 1126-1131, 2015.

91 Haeggblom L, Nordfors C, Tertipis N, Bersani C, Ramqvist T, Nasman A and Dalianis T: Effects of irradiation on human leukocyte antigen class I expression in human papillomavirus positive and negative base of tongue and mobile tongue squamous cell carcinoma cell lines. Int J Oncol, 2017. doi: 10.3892/ijo.2017.3916. [Epub ahead of print]

92 Spanos WC, Nowicki P, Lee DW, Hoover A, Hostager B, Gupta $\mathrm{A}$, Anderson $\mathrm{ME}$ and Lee $\mathrm{JH}$ : Immune response during therapy with cisplatin or radiation for human papillomavirus-related head and neck cancer. Arch Otolaryngol Head Neck Surg 135: 1137-1146, 2009.

93 Bykov VJ and Wiman KG: Mutant p53 reactivation by small molecules makes its way to the clinic. FEBS Lett 588: 26222627, 2014.

94 Ogino S, Nosho K, Kirkner GJ, Shima K, Irahara N, Kure S, Chan AT, Engelman JA, Kraft P, Cantley LC, Giovannucci EL and Fuchs CS: PIK3CA mutation is associated with poor prognosis among patients with curatively resected colon cancer. J Clin Oncol 27: 1477-1484, 2009.

95 He Y, Van't Veer LJ, Mikolajewska-Hanclich I, van Velthuysen ML, Zeestraten EC, Nagtegaal ID, van de Velde CJ and Marijnen CA: PIK3CA mutations predict local recurrences in rectal cancer patients. Clin Cancer Res 15: 6956-6962, 2009.

96 De Roock W, Claes B, Bernasconi D, De Schutter J, Biesmans B, Fountzilas G, Kalogeras KT, Kotoula V, Papamichael D,
Laurent-Puig P, Penault-Llorca F, Rougier P, Vincenzi B, Santini D, Tonini G, Cappuzzo F, Frattini M, Molinari F, Saletti P, De Dosso S, Martini M, Bardelli A, Siena S, Sartore-Bianchi A, Tabernero J, Macarulla T, Di Fiore F, Gangloff AO, Ciardiello F, Pfeiffer P, Qvortrup C, Hansen TP, Van Cutsem E, Piessevaux H, Lambrechts D, Delorenzi $M$ and Tejpar S: Effects of KRAS, BRAF, NRAS, and PIK3CA mutations on the efficacy of cetuximab plus chemotherapy in chemotherapyrefractory metastatic colorectal cancer: a retrospective consortium analysis. Lancet Oncol 11: 753-762, 2010.

97 Garcia-Carracedo D, Villaronga MA, Alvarez-Teijeiro S, Hermida-Prado F, Santamaria I, Allonca E, Suarez-Fernandez L, Gonzalez MV, Balbin M, Astudillo A, Martinez-Camblor P, $\mathrm{Su}$ GH, Rodrigo JP and Garcia-Pedrero JM: Impact of $\mathrm{PI} 3 \mathrm{~K} / \mathrm{AKT} / \mathrm{mTOR}$ pathway activation on the prognosis of patients with head and neck squamous cell carcinomas. Oncotarget 7: 29780-29793, 2016.

98 Isaacsson Velho PH, Castro G, Jr. and Chung CH: Targeting the PI3K Pathway in Head and Neck Squamous Cell Carcinoma. Am Soc Clin Oncol Educ Book: 123-128, 2015.

99 von Massenhausen A, Deng M, Billig H, Queisser A, Vogel W, Kristiansen G, Schrock A, Bootz F, Goke F, Franzen A, Heasley L, Kirfel J, Bragelmann J and Perner S: Evaluation of FGFR3 as a therapeutic target in head and neck squamous cell carcinoma. Target Oncol 11: 631-642, 2016.

100 Rosty C, Aubriot MH, Cappellen D, Bourdin J, Cartier I, Thiery JP, Sastre-Garau X and Radvanyi F: Clinical and biological characteristics of cervical neoplasias with FGFR3 mutation. Mol Cancer 4: 15, 2005.

101 Liao RG, Jung J, Tchaicha J, Wilkerson MD, Sivachenko A, Beauchamp EM, Liu Q, Pugh TJ, Pedamallu CS, Hayes DN, Gray NS, Getz G, Wong KK, Haddad RI, Meyerson M and Hammerman PS: Inhibitor-sensitive FGFR2 and FGFR3 mutations in lung squamous cell carcinoma. Cancer Res 73: 5195-5205, 2013.

102 Tabernero J, Bahleda R, Dienstmann R, Infante JR, Mita A, Italiano A, Calvo E, Moreno V, Adamo B, Gazzah A, Zhong B, Platero SJ, Smit JW, Stuyckens K, Chatterjee-Kishore M, Rodon J, Peddareddigari V, Luo FR and Soria JC: Phase I Dose-Escalation Study of JNJ-42756493, an Oral PanFibroblast Growth Factor Receptor Inhibitor, in Patients With Advanced Solid Tumors. J Clin Oncol 33: 3401-3408, 2015.

103 Nogova L, Sequist LV, Perez Garcia JM, Andre F, Delord JP, Hidalgo M, Schellens JH, Cassier PA, Camidge DR, Schuler M, Vaishampayan U, Burris H, Tian GG, Campone M, Wainberg ZA, Lim WT, LoRusso P, Shapiro GI, Parker K, Chen X, Choudhury S, Ringeisen F, Graus-Porta D, Porter D, Isaacs R, Buettner R and Wolf J: Evaluation of BGJ398, a Fibroblast Growth Factor Receptor 1-3 Kinase Inhibitor, in Patients With Advanced Solid Tumors Harboring Genetic Alterations in Fibroblast Growth Factor Receptors: Results of a Global Phase I, Dose-Escalation and Dose-Expansion Study. J Clin Oncol 35: 157-165, 2017.

104 Hammerman PS, Hayes DN and Grandis JR: Therapeutic insights from genomic studies of head and neck squamous cell carcinomas. Cancer Discov 5: 239-244, 2015.

105 Karkera JD, Martinez Cardona G, Bell K, Gaffney D, Portale JC, Santiago-Walker A, Moy C, King P, Sharp M, Bahleda R, Luo FR, Alvarez JD, Lorenzi MV and Platero SJ: Oncogenic characterization and pharmacologic sensitivity of activating 
fibroblast growth factor receptor (FGFR) genetic alterations to the selective FGFR inhibitor erdafitinib. Mol Cancer Ther 16(8): 1717-1726, 2017.

106 Slebos RJ, Yi Y, Ely K, Carter J, Evjen A, Zhang X, Shyr Y, Murphy BM, Cmelak AJ, Burkey BB, Netterville JL, Levy S, Yarbrough WG and Chung $\mathrm{CH}$ : Gene expression differences associated with human papillomavirus status in head and neck squamous cell carcinoma. Clin Cancer Res 12: 701-709, 2006.

107 Strigari L, Pinnaro P, Carlini P, Torino F, Strolin S, Minosse S, Sanguineti G and Benassi M: Efficacy and mucosal toxicity of concomitant chemo-radiotherapy in patients with locallyadvanced squamous cell carcinoma of the head-and-neck in the light of a novel mathematical model. Crit Rev Oncol Hematol 102: 101-110, 2016.
108 Mitra A, MacIntyre DA, Marchesi JR, Lee YS, Bennett PR and Kyrgiou M: The vaginal microbiota, human papillomavirus infection and cervical intraepithelial neoplasia: what do we know and where are we going next? Microbiome 4: 58, 2016.

Received August 10, 2017

Revised September 1, 2017 Accepted September 5, 2017 